УДК 2 - 284 : 811.161’373.46

Кучер О. М., Медведь О. В.

doi:10.32620/gch.2019.3.07

\title{
ДО ПРОБЛЕМИ СИСТЕМАТИЗАЦІї БОГОСЛОВСЬКОЇ ТЕРМІНОЛОГІЇ В ОСВІТНЬОМУ ПРОЦЕСІ
}

У статті акиентовано необхідність упорядкування богословської термінології в освітньому прочесі. Розглянуто певні розбіжності тлумачення сутності богослов'я як науки в академічному релігієзнавстві й сучасній богословській практиці, висвітлено його конфесійний поділ і внутрішню диференціацію на окремі дисципліни. Підкреслено роль богословських текстів, канонічних для кожної окремої конфесії чи навіть помісних иерков, обтрунтовано значення цих текстів як джерела богословських термінів в освітньому nрочесі.

Ключові слова: богослов'я, богословська освіта, богословська термінологія, конфесійно-богословська термінологія.

The article emphasizes the importance of systematization of theological terms in education. It discusses the discrepancies in the definition of theology as a science in academic religious studies and contemporary theological practice and highlights its divisions. The article also stresses the role of theological texts that are canonical for a specific religion or church and explains the significance of these texts as a source for theological terms in education.

Keywords: theology, theological education, theological terms, confessional theological terms.

В умовах зрушень, що відбулися протягом останніх десятиліть в українському суспільстві, його науковому й освітньому просторі, богослов'я активізувало розвиток як окреме вчення, що має свій предмет пізнання, хоча й перебуває поза межами академічної науки в іiї класичному розумінні. У той же час надання богослов'ю місця в системі галузей знань і спеціальностей, за якими здійснюється підготовка здобувачів вищої освіти, ставить питання про системний опис i, у разі потреби, подальше впорядкування лексичних засобів теологічної освіти.

Українська релігійна лексика в цілому та іiі окремі лексико-семантичні групи, називані відповідно до об’єкта конкретного дослідження «релігійна термінологія», «церковна термінологія», «богослужбова термінологія», «сакральна термінологія», «богословська термінологія» та ін., неодноразово були об'єктом мовознавчих студій. Не викликає сумніву, що мовознавці при цьому спираються на екстралінгвістичні поняття «релігія», «церква», «сакральне», «богослов’я» тощо. Варто відзначити, що, описуючи склад і організацію термінології релігійної сфери, науковці окреслюють іiі межі, виходячи із суто практичних потреб свого лінгвістичного дослідження. Так, наприклад, в окремих роботах вітчизняних учених досліджено конкретні релігійні лексеми або групи таких лексем: С.В. Бібла проаналізувала склад, джерела й шляхи формування української церковної термінології, грунтуючись на назвах церковних чинів та посад [1], Н.В. Пуряєва - формування української церковно-обрядової термінології на матеріалі назв богослужбових предметів [11], С. Яремчук - систему 
богословських термінів на прикладі окремих лексем $[15,16]$. Натомість в інших мовознавчих студіях розглянуто релігійну термінологію чи терміногрупу в її складі в цілому: I.I. Ворона подала характерні ознаки й особливості церковно-релігійної термінології [2], Г.М. Наконечна - характеристику богословської термінології як системи [5], Ю.В. Осінчук - історію богослужбово-обрядової лексики української мови [7].

У контексті пропонованого дослідження надзвичайно цікавими видаються наукові розвідки, у яких простежено богословські терміни безпосередньо у сфері їхнього функціонування - у богослужбовій (літургійній) практиці й відповідних богословських текстах. Наприклад, Н.В. Пуряєва схарактеризувала функціонування української мови в літургійні практиці українських церков [10], а також проблемні питання мови богослужіння взагалі та словник мови богослужіння зокрема [9]; Б. Огульчанський дослідив розвиток української богословської термінології в літургійних і богословських текстах від епохи модерну до новітніх часів [6]. Однак розвиток богословської освіти в Україні робить актуальним питання про пї термінологічний супровід.

Мета пропонованої статті - окреслити проблему систематизації богословської термінології в освітньому процесі, наявну в сучасній суспільній і науковій практиці. Відповідно завдання дослідження полягають у тому, щоб розглянути особливості богослов'я як учення й богословської освіти в суспільній практиці й освітньому просторі сучасної України, акцентувати їхню конфесійну спрямованість, багато в чому визначену богословськими текстами, якими користуються під час дослідницької й освітньої діяльності.

Зважаючи на певні історичні чинники, на сьогодні у вітчизняній суспільній практиці в трактуванні релігійних понять достатньо вагомим залишається влив релігієзнавства як академічної науки. У релігієзнавчих джерелах термін «богослов’я» (хоча, варто відзначити, більш уживаним є термін «теологія») не має однозначної дефініції й навіть постає полісемічним. Так, наприклад, у «Юридичній енциклопедії» подано таке визначення аналізованого поняття: «Богослов’я (грец. від - Бог і вчення) - система обгрунтування і захисту релігійних вчень про Бога, сукупність вироблених певною релігією доказів істинності догматики, релігійної моралі, правил і норм життя духівництва та віруючих, боговстановленості церкви та їі віровчення» [17]. Натомість в «Енциклопедії історії України» наведено таке тлумачення: «Теологія (грец.

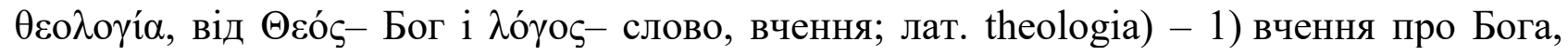
інтерпретоване як осмислення i доказ абсолютної істини, що міститься в Божественному Одкровенні; 2) систематичний виклад та обгрунтування догматів певної релігії, засновані на іiі вченні про Бога та священних книгах; 3) навчальна дисципліна, в якій представлено вчення про Бога й систематичний виклад догматів у контексті віросповідання i канонів певної релігії, iii iсторико-культурного i соціоетичного досвіду» [4].

На нашу думку, релігієзнавчі підходи до визначення теології не втрачають актуальності насамперед тому, що є більш системними й унаслідок цього придатними для прикладних досліджень. Так, наприклад, у межах академічного релігієзнавства 
відповідно до наявних віровчень про Бога в складі теології виділяють юдейське, християнське, мусульманське, індуїстське, буддійське та ін. богослов'я. Відповідно в християнстві розрізняють богослов'я католицьке, богослов'я православне й богослов'я протестантське.

Богослов'я як учення становить комплекс дисциплін, кожна 3 яких стосується різних аспектів віровчення й культу, має своє цільове призначення (див., наприклад, [17]). Так, наприклад, у православ'ї до цього комплексу зараховують основне, або апологетичне, богослов'я (апологетику), головне завдання якого полягає в обгрунтуванні й захист основних християнських положень у суперечках із вірянами інших конфесій або тими, хто не вірить; біблійне (біблейське) богослов'я, яке опікується вивченням історії Святого Письма та його тлумаченням на основі творів святих отців і знаних богословів християнства; догматичне богослов'я, що доводить істинність релігійних догматів, викладених у християнському символі віри; моральне, або практичне, богослов'я, яке стосується дій християнина в земному житті; викривальне, або порівняльне, богослов'я, що покликане розкривати переваги православ'я перед іншими релігіями.

Також загальновизнаним є поділ православного богослов'я на такі богословські дисципліни, що розкривають сутність віри, як тріадологія (учення про Святу Трійцю Бога-Отця, Бога-Сина, Бога - Духа Святого), христологія (учення про Божественну та людську природи Ісуса Христа), пневматологія (учення про Святого Духа як Третьої Особи Святої Трійці), маріологія (учення про Богородицю, Пречисту Діву Марію), еклезіологія (учення про Церкву як соціальне і духовне (містичне) Тіло Ісуса Христа, есхатологія (учення про останні часи історії людства та перебування душ людей у загробному світі), сотеріологія (учення про спасіння), сакраментологія (учення про таїнства Церкви), патрологія, або патристика (учення про богословську й духовну спадщину святих отців Церкви).

У той же час на противагу академічному релігієзнавству в суто богословських джерелах вихідне аналізоване поняття «богослов’я» позбавлене академізму: «У християнському вжитку термін богослов'я може мати ширше значення «наука або мова про Бога на основі Божого об'явлення» або більш специфічне - «пізнання Бога у його внутрішньому житті» [14]. Цікавим у цьому аспекті видається й побіжне зауваження в загальнодоступних довідкових джерелах, що останнім часом у православних богословів спостерігається поступова відмова від систематичного викладу за строго визначеними розділами, перевага надається сприйняттю богослов'я у його цілісності, без поділу на автономні частини [8].

Своєю чергою, богословська освіта в Україні зазнала протягом останніх десятиліть бурхливого розвитку: згідно зі «Звітом про мережу релігійних організацій в Україні станом на 1 січня 2019 року», у країні нараховувалося 204 духовних навчальних заклади, серед них 136 вищих і 68 середніх закладів духовної освіти [3].

Питання про богослов'я як самостійну галузь знань актуалізувалося після 29 квітня 2002 р., коли міністр освіти і науки України підписав наказ № 280, згідно 3 яким богослов'я (теологія) було внесено до державного переліку напрямів та спеціальностей, за якими на той час здійснювалася підготовка здобувачів вищої 
освіти.

За наказом Міністерства освіти і науки України № 363 від 16.06.2005 p. бакалаври, спеціалісти і магістри за фахом богослов’я (теологія) готувалися в межах напряму підготовки «Філософія» на підставі постанови Кабінету Міністрів України № 507 від 24.05.1997 р. Пізніше, згідно з урядовою постановою № 1719 від 13.12.2006 р., цю спеціальність було вилучено з переліку напрямів підготовки бакалаврів. Із цього часу й до пізніших змін спеціалісти й магістри богослов'я (теології) готувалися в Україні на базі освітньо-кваліфікаційного рівня бакалавра філософії. Згідно 3 постановою № 787 від 27.12.2010 р. богослов’я (теологія) було залишено в переліку спеціальностей, за якими здійснюється підготовка фахівців і магістрів у межах галузі знань «Гуманітарні науки». Для виконання цієї постанови Кабінету Міністрів цей перелік був введений в дію Наказом Міністерства освіти і науки України № 1067 від 9 листопада 2010 р. Постановою Кабінету Міністрів України № 267 від 17 березня 2011 р. було введено розмежування богословів за конфесійною ознакою, у тому числі й серед магістрів.

У 2017 р. було оприлюднено «Стандарт вищої освіти України першого (бакалаврського) рівня галузі знань 04 - богослов'я, спеціальності 041 - богослов'я» [12] та «Стандарт вищої освіти України другого (магістерського) рівня галузі знань 04 - богослов'я, спеціальності 041 - богослов'я» [13]. За цими стандартами, «nid богословською освітою розуміється широке за змістом поняття: (1) освіта в вищому духовному навчальному закладі, яка визначається окремо взятою конфесією i орієнтована передусім на підготовку професіоналів (науковців, викладачів богословських ВНЗ, вчителів недільних шкіл, кандидатів на пастирське служіння, регентів церковних хорів тощо), в центрі підготовки яких знаходиться систематичне навчання і вивчення віровчення конфесії; (2) освіта в інших вищих навчальних закладах, яка може бути не пов язана 3 жодною 3 конфесій та орієнтована на підготовку фахівців, що могли б реалізуватися на різних суспільних посадах (учитель предметів духовно-морального спрямування, викладач богословських дисциплін у ВН3 тощо)» [12]. Відповідно до наведеного визначення, богословська освіта має два напрямки: конфесійно спрямований і «позаконфесійний».

Важливо підкреслити, що одним із основних методів богослов'я й відповідно богословської освіти 3 найдавніших часів і дотепер $є$ дослідження й осмислення священних текстів і коментарів до них, зроблених відомими богословами в різні часи.

Ці тексти відрізняються в різних конфесіях і навіть у межах однієї для помісних церков, що, зокрема, характерне для християн східного обряду.

Наприклад, головним об'єктом християнського богослов'я визнано «Святе Письмо в історичному процесі формування його канону, передаванні тексту й інтерпретації змісту» [6]. Однак Б. Огульчанський, досліджуючи затверджені тексти, якими користуються основні церкви України східного обряду, слушно вказує, що це різні переклади Святого Письма: Біблія (книги Священного Писання Старого та Нового Завіту), переклад патріарха Філарета (Денисенка) - основний текст для УПЦ КП; Святе Письмо Старого та Нового Завіту. Переклад о. Івана Хоменка - ним користується УГКЦ; Богослужбове Свангеліє (видання Київської Митрополії УПЦ) та 
Новий Завіт (видання Волинської єпархії УПЦ) - ними користуються в УПЦ [6]. Автор також констатує: «С також інші переклади, які, хоч i не мають статус офіційних, все ж мають значний авторитет. Це Біблія у перекладі архімандрита Рафаїла (Турконяка); Новий Заповіт сучасною мовою (UMT), World Bible Translation Centre; "Вічне Свангеліє" (переклад В. Громова) та інші. Додамо також, що переклад Івана Огієнка (митр. Іларіона) залишається авторитетним для нецерковних видань, $\mathrm{i}$ більшість освітніх, наукових, публіцистичних та культурологічних видань, які цитують текст Св. Письма, цитують його саме за перекладом Огієнка» [6].

Переконливими видаються зауваження Б. Огульчанського про лексику й термінологію цих перекладів: «Про що свідчить лексика цих перекладів? 3 урахуванням того, що названі тут переклади є в основному плодами творчої копіткої праці перекладачів (а також компетентного колективу редакторів), кожен 3 них має свої певні принципи перекладу і тезаурус термінів. Хоча переклади тих чи інших місць Св. Письма не завжди несуть той самий зміст (втім, для текстів Нового Завіту серйозних розходжень майже немає), вони різноманітні i стилістично, i за перекладацькими підходами - давніші переклади намагаються зберігати принцип "слово перекладаємо словом", в той час як новіші переклади деінде в тексті $\epsilon$ перекладами сенсів» [6].

Наведені міркування свідчать, на наш погляд, про одну 3 вагомих причин невпорядкованості сучасної богословської термінології, водночас накреслюючи й можливі шляхи іiі подолання, що важливо не тільки для богослужбової практики й теоретичного богослов'я, але й для вітчизняної богословської освіти.

Проведений вище аналіз розвитку сучасного богослов'я й богословської освіти, а також власне богословської термінології дозволяє, на наш погляд, визначити кілька взаємопов'язаних аспектів проблеми впорядкування богословської термінології в освітньому процесі.

По-перше, сучасне богословське вчення перебуває під впливом двох протилежних «течій»: з одного боку, не втрачають актуальності релігієзнавчі підходи до визначення теології, 3 другого - поступово починає формуватися сприйняття богослов'я у його цілісності, без поділу на автономні частини. По-друге, оприлюднені проєкти стандартів богословської вищої освіти, своєю чергою, передбачають дві іiі напрямки: конфесійно спрямований і «позаконфесійний». По-третє, дослідження й осмислення священних текстів і коментарів до них, зроблених відомими богословами в різні часи, передбачає свідоме врахування того, що ці тексти відрізняються в різних конфесіях і навіть у межах однієї для помісних церков, грунтуються на різних принципах перекладу.

Отже, для вирішення наявної в сучасній суспільній і науковій практиці проблеми впорядкування богословської термінології в освітньому процесі необхідно, на наш погляд, ураховувати всі тенденції розвитку сучасного богослов’я й відповідної освіти, а також власне богословської термінології. 


\section{Література:}

1. Бібла С. В. Склад, джерела і шляхи формування української церковної термінології (назви церковних чинів та посад) : автореф. дис. на здобуття наук. ступеня канд. філол. наук : спец. 10.02.01 «Українська мова». Київ, 1997. 20 с.

2. Ворона I. I. Характеристика української церковно-релігійної термінології. Науковий вісник Міжнародного гуманітарного університету. Сер. : Філологія. № 23. Том 1. Одеса, 2016. С. 14-16.

3. Звіт про мережу релігійних організацій в Україні станом на 1 січня 2019 року [Електронний pecypc]. URL : mincult.kmu.gov.ua > document (дата звернення : 1 червня 2019 p.).

4. Любащенко В. I. Теологія. Енциклопедія історії Украйни: у 10 т./ редкол. : В. А. Смолій (голова) та ін. ; Інститут історії України НАН України. Київ : Наук. думка, 2013. Т. $10:$ Т -Я. С. 49.

5. Наконечна Г. Українська богословська термінологія: характеристика системи. Християнство и українська мова: матеріали наукової конферениї (Київ, 5-6 жовтня 2000 р.) / відп. ред.: В. Німчук. Львів, 2000. С. 79-92.

6. Огульчанський Б. Розвиток української богословської термінології в літургійних і богословських текстах від епохи модерну до новітніх часів [Електронний ресурс]. URL : http://www.ruslang.ru/doc/church-slav/sjezd2018/2_Bogdan_Ogulchanskij.pdf (дата звернення : 1 червня 2019 p.).

7. Осінчук Ю. В. Історія богослужбово-обрядової лексики української мови : автореф. дис. на здобуття наук. ступеня канд. філол. наук: спец. 10.02.01. Київ, 2008. 20 с.

8. Православне богослов’я. [Електронний ресурс]. URL :https:// uk.wikipedia.org > wiki >

9. Пуряєва Н. Дещо про мову богослужіння взагалі та про словник мови богослужіння зокрема. Лексикографічний бюлетень. 2004. Вип. 10. С. 36-42.

10. Пуряєва Н. Українська мова в літургійній практиці українських церков. Проблеми гуманітарних наук: зб. наук. праџь Дрогобищького державного педагогічного університету імені Івана Франка. Серія “Філологія. Випуск 42”. 2018. С. 128-146.

11. Пуряєва Н. Формування української церковно-обрядової термінології (назви богослужбових предметів) : автореф. дис. ... канд. філол. наук : спец. 10.02.01 «Українська мова»; НАН України, ін-т укр. мови. Київ, 2001. 20 с.

12. Стандарт вищої освіти України першого (бакалаврського) рівня галузі знань 04 богослов'я, спеціальності 041 - богослов'я [Електронний ресурс]. URL : https://mon.gov.ua > app > vyshcha > 041-standart-z-bogoslovya-bakalavr-1 (дата звернення : 1 червня 2019 p.).

13. Стандарт вищої освіти України другого (магістерського) рівня галузі знань 04 - богослов'я, спеціальності 041 - богослов'я [Електронний ресурс]. URL : https://mon.gov.ua > vyshcha > 041bogoslovya-magistr-31.05.2017.doc (дата звернення : 1 червня 2019 р.).

14. Термінологічно-правописний порадник для богословів та редакторів богословських текстів [Електронний ресурc]. URL : http://poradnyk.ucu.edu.ua/theological-comments/theology/

15. Яремчук С.Система богословських термінів: семантика лексем амвон, вівтар, ікона. Проблеми украӥнської термінології: міжнар. наук. конф., 1-2 жовт. 2010 р. : зб. наук. пр. Львів, 2010. С. $115-117$.

16. Яремчук С. Вивчення сакральної та богословської термінології на заняттях з української мови як іноземної. Теорія і практика викладання української мови як іноземної : зб. наук. праць. Львів: Видавничий центр ЛНУ ім. І. Франка, 2011. Вип. 6. С. 117-120.

17. Яроцький П. Л. Теологія. Юридична енциклопедія : у 6 т. / Ю. С. Шемшученко (відп. ред.) та ін. Київ : Українська енциклопедія ім. М. П. Бажана, 1998-2004. Т. 6. 


\section{References:}

1. Bibla, S. V. (1997), Sklad, dzherela i shlyakhy formuvannya ukrayins'koyi tserkovnoyi terminolohiyi (nazvy tserkovnykh chyniv ta posad) [Composition, sources and ways of formation of Ukrainian ecclesiastical terminology (names of church ranks and posts)], $20 \mathrm{p}$.

2. Vorona, I. I. (2016), "Kharakterystyka ukrayins'koyi tserkovno-relihiynoyi terminolohiyi" [Characteristics of Ukrainian Church-Religious Terminology], Naukovyy visnyk Mizhnarodnoho humanitarnoho universytetu, series "Filolohiya", No 23, Vol. 1. Odesa, pp. 14-16.

3. Report on the Network of Religious Organizations in Ukraine as of January 1, 2019. [Electronic resource], available at : mincult.kmu.gov.ua >document (accessed June 1, 2019).

4. Lyubashchenko, V. I. (2013), Teolohiya [Theology], Entsyklopediya istoriyi Ukrayiny : u 10 t., Instytut istoriyi Ukrayiny NAN Ukrayiny, Nauk. dumka, Kyiv, Vol. 10, T-Ya, p. 49.

5. Nakonechna, H. (2000), "Ukrayins'ka bohoslovs'ka terminolohiya: kharakterystyka systemy" [Theological Terminology: Characterization of the System], Khrystyyanstvo y ukrayins'ka mova: materialy naukovoyi konferentsiyi (Kyiv, 5-6 zhovtnya 2000 r.), L'viv, pp. 79-92.

6. Ohul'chans'kyy, B. "Rozvytok ukrayins'koyi bohoslovs'koyi terminolohiyi $v$ liturhiynykh $i$ bohoslovs'kykh tekstakh vid epokhy modernu do novitnikh chasiv" [Development of Ukrainian Theological Terminology in Liturgical and Theological Texts from the Modernist Era to Modern Times], available at : http://www.ruslang.ru/doc/church-slav/sjezd2018/2_Bogdan_Ogulchanskij.pdf (accessed : June 1, 2019).

7. Osinchuk, Y. V. (2008), Istoriya bohosluzhbovo-ōbryadovoyi leksyky ukrayins'koyi movy [History of liturgical and ritual vocabulary of the Ukrainian language], Kyiv, $20 \mathrm{p}$.

8. Pravoslavne bohoslov"ya [Orthodox theology], available at : https://uk.wikipedia.org > wiki > Православне_богослов'я

9. Puryayeva, N. (2004), "Deshcho pro movu bohosluzhinnya vzahali ta pro slovnyk movy bohosluzhinnya zokrema" [Something about the language of worship in general and the dictionary of the language of worship in particular], Leksykohrafichnyy byuleten', Vol. 10, pp. 36-42.

10. Puryayeva, N. (2018), "Ukrayins'ka mova v liturhiyniy praktytsi ukrayins'kykh tserkov" [Ukrainian in the liturgical practice of Ukrainian churches]. Problemy humanitarnykh nauk : zb. nauk. prats' Drohobyts'koho derzhavnoho pedahohichnoho universytetu imeni Ivana Franka, seriya "Filolohiya. Vypusk 42", pp. 128-146.

11. Puryayeva, N. (2001), Formuvannya ukrayins'koyi tserkovno-obryadovoyi terminolohiyi (nazvy bohosluzhbovykh predmetiv) [Formation of Ukrainian Church-Ritual Terminology (names of liturgical subjects)], NAN Ukrayiny, In-t ukr. movy, Kyiv, 20 p.

12. Standart vyshchoyi osvity Ukrayiny pershoho (bakalavrs'koho) rivnya haluzi znan' 04 bohoslov"ya, spetsial'nosti 041 - bohoslov"ya [Higher Education Standard of Ukraine first (bachelor) level of knowledge 04 - theology, specialty 041 - theology], available at ://mon.gov.ua > app > vyshcha > 041standart-z-bogoslovya-bakalavr-1 (accessed : 1 chervnya 2019).

13. Standart vyshchoyi osvity Ukrayiny druhoho (mahisters'koho) rivnya haluzi znan' 04 bohoslov"ya, spetsial'nosti 041 - bohoslov"ya [Higher education standard of Ukraine second (master's) level of knowledge 04 - theology, specialty 041 - theology ]. available at : https://mon.gov.ua > vyshcha > 041bogoslovya-magistr-31.05.2017.doc ( accessed: 1 chervnya 2019 r.).

14. Terminolohichno-pravopysnyy poradnyk dlya bohosloviv ta redaktoriv bohoslovs'kykh tekstiv [Terminological and spelling adviser for theologians and editors of theological texts], available at: http://poradnyk.ucu.edu.ua/theological-comments/theology/

15. Yaremchuk, S. (2010), "Systema bohoslovs'kykh terminiv: semantyka leksem amvon, vivtar, ikona" [The system of theological terms: semantics of lexemes pulpit, altar, icon.], Problemy ukrayins'koyi terminolohiyi: mizhnar. nauk. konf., 1-2 zhovt. 2010 r. : zb. nauk. pr., L'viv, pp. 115-117.

16. Yaremchuk, S. (2011), Vyvchennya sakral'noyi ta bohoslovs'koyi terminolohiyi na zanyattyakh z ukrayins'koyi movy yak inozemnoyi. Teoriya i praktyka vykladannya ukrayins'koyi movy yak inozemnoyi [Studying Sacred and Theological Terminology in Classes in Ukrainian as a Foreign Language. Theory and 
Practice of Teaching Ukrainian as a Foreign Language], Vydavnychyy tsentr LNU im. I. Franka, L'viv, Vol. 6, pp. 117-120.

17. Yarots'kyy, P. L. (1998-2004), Teolohiya [Theology], Yurydychna entsyklopediya : u 6 t./ Y. S. Shemshuchenko (vidp. red.) ta in.: Ukrayins'ka entsyklopediya im. M. P. Bazhana, Kyiv, Vol. 6.

\section{Oleh Kucher, Olena Medved}

\section{ON THE PROBLEM OF SYSTEMATIZATION OF THEOLOGICAL TERMS IN EDUCATION}

The establishment of theology as an academic discipline raises the question of the normalization of its lexical means.

Ukrainian religious vocabulary as a whole, and, in particular, its certain lexicalsemantic groups referred to as "religious terms", "church terms", "sacred terms", "theological terms" and others based on a subject matter, have been the subject of many linguistic studies. Of particular interest to this research are the studies focused on theological terms in the area of their usage - theological (liturgical) practice and corresponding theological texts. For instance, N.V. Puriaieva gave a characterization of the usage of the Ukrainian language in the liturgical practice of Ukrainian churches, problems of a sacred language, and the vocabulary of church service terms; B. Ogulchanskiy studied the development of Ukrainian theological terms in liturgical and theological texts from the Art Nouveau period to the present. Nevertheless, the development of theological education in Ukraine makes it important to standardize theological terms used in the education process.

Considering certain historical factors, religious studies still have a great influence on the interpretation of religious concepts in the scientific community. This discipline uses the more standardized approaches allowing to use them for applied research. For example, religious studies distinguish the following beliefs about God withing theology: Jewish, Christian, Muslim, Hindu, Buddhist theology, etc. Christianity is divided into Catholic, Orthodox, and Protestant theology. Eastern Orthodoxy includes apologetic theology (apologetics), biblical theology, dogmatic theology, moral or practical theology, comparative theology, etc.

Compared to religious studies, the term "theology" lacks consistency in theological sources.

The study and understanding of sacred texts and eminent theologians' commentaries to them have been one of the main theological methods from the earliest times. These texts vary among confessions and even withing one church, which is especially common for Eastern Christianity.

In our opinion, this analysis points to the reason for the incoherency of the modern theological terms and outlines the possible ways of eliminating it which is essential not only for theological practice but also for theological education.

Keywords: theology, theological education, theological terms, confessional theological terms. 


\section{Олег Кучер, Олена Медведь}

\section{ДО ПРОБЛЕМИ СИСТЕМАТИЗАЦЇ̈ БОГОСЛОВСЬКОЇ ТЕРМІНОЛОГІЇ В НАВЧАЛЬНОМУ ПРОЦЕСІ}

Надання богослов'ю місця в системі галузей знань і спеціальностей, за якими здійснюється підготовка здобувачів вищої освіти, ставить питання про впорядкування лексичних засобів богословської освіти.

Українська релігійна лексика в цілому та іiі окремі лексико-семантичні групи, називані відповідно до об'єкта конкретного дослідження «релігійна термінологія», «церковна термінологія», «богослужбова термінологія», «сакральна термінологія», «богословська термінологія» та ін., неодноразово були об'єктом мовознавчих студій. У контексті пропонованого дослідження надзвичайно цікавими видаються наукові розвідки, у яких простежено богословські терміни безпосередньо у сфері їхнього функціонування - у богослужбовій (літургійній) практиці й відповідних богословських текстах. Наприклад, Н.В. Пуряєва схарактеризувала функціонування української мови в літургійні практиці українських церков, а також проблемні питання мови богослужіння взагалі та словник мови богослужіння зокрема; Б. Огульчанський дослідив розвиток української богословської термінології в літургійних і богословських текстах від епохи модерну до новітніх часів. У той же час не викликає сумніву, що розвиток богословської освіти в Україні робить актуальним питання про іiі термінологічний супровід, про впорядкування богословських термінів у навчальному процесі.

Зважаючи на певні історичні чинники, на сьогодні у вітчизняній суспільній практиці в трактуванні релігійних понять достатньо вагомим залишається влив релігієзнавства як академічної науки. Релігієзнавчі підходи до визначення теології не втрачають актуальності насамперед тому, що є більш системними й унаслідок цього придатними для прикладних досліджень. Так, наприклад, у межах академічного релігієзнавства відповідно до наявних віровчень про Бога в складі теології виділяють юдейське, християнське, мусульманське, індуїстське, буддійське та ін. богослов'я. Відповідно в християнстві розрізняють богослов'я католицьке, богослов'я православне й богослов'я протестантське. У православ'ї до цього комплексу зараховують основне, або апологетичне, богослов'я (апологетику), біблійне (біблейське) богослов'я, догматичне богослов'я, моральне, або практичне, богослов'я, викривальне, або порівняльне, богослов'я, та ін.

У той же час на противагу академічному релігієзнавству в суто богословських джерелах вихідне аналізоване поняття «богослов'я» позбавлене системності.

Важливо підкреслити, що одним з основних методів богослов'я 3 найдавніших часів і дотепер є дослідження й осмислення священних текстів і коментарів до них, зроблених відомими богословами в різні часи. Ці тексти відрізняються в різних конфесіях і навіть у межах однієї для помісних церков, що, зокрема, характерне для християн східного обряду. 
Наведені міркування свідчать, на наш погляд, про одну з вагомих причин невпорядкованості сучасної богословської термінології, водночас накреслюючи й можливі шляхи іiі подолання, що важливо не тільки для богослужбової практики й теоретичного богослов'я, але й для вітчизняної богословської освіти.

Ключові слова: богослов'я, богословська освіта, богословська термінологія, конфесійно-богословська термінологія.

Kucher Oleh - Senior Lecturer of the Department of Documentation and Ukrainian Language Faculty of Humanities of the National Aerospace University «Kharkiv Aviation Institute».

Кучер Олег - старший викладач кафедри документознавства та української мови гуманітарного факультету Національного аерокосмічного університету ім. М. Є. Жуковського «Харківський авіаційний інститут».

e-mail: olku@ua.fm

Medved Olena - Ph.D. in Philology, Associate Professor, Associate Professor of the Department of Documentation and Ukrainian Language Faculty of Humanities of the National Aerospace University «Kharkiv Aviation Institute».

Медведь Олена - кандидат філологічних наук, доцент, доцент кафедри документознавства та української мови гуманітарного факультету Національного аерокосмічного університету ім. М. С. Жуковського «Харківський авіаційний інститут».

e-mail: elenamdvd@gmai.com

Надійшла до редакції 12.06.2019. Розглянута на редколегії 27.08.2019.

\section{Рецензенти:}

Доктор філософських наук, професор, декан гуманітарного факультету Національного аерокосмічного університету ім. М. Є. Жуковського «Харківський авіаційний інститут» Копилов В. О.

Доктор філософських наук, професор кафедри філософії Національного аерокосмічного університету ім. М. Є. Жуковського «Харківський авіаційний інститут» Кузнецов А. Ю. 